\title{
KEPALA SEKOLAH SEBAGAI PENDIDIK DAN PENGAWAS DALAM MENINGKATKAN KOMPETENSI PEDAGOGIK GURU
}

\author{
Nellitawati; Aswardi; Arwildayanto \\ Universitas Negeri Padang-Padang \\ Universitas Negeri Padang-Padang \\ Universitas Negeri Gorontalo-Gorontalo \\ nellitawati@fip.unp.ac.id
}

\begin{abstract}
Indonesian education is being talked about the competence of teachers, in relation to the principal role in improving the teachers pedagogical aspect. The main aim of this study was to determine the education and supervision role of principal in enhancing the pedagogic aspect of teachers in the Vocational School in the Padang City, West Sumatera, Indonesia. Concurrent embedded mixed method research design was provided as a guidance in the process to gain the research objectives. This study delivers questionnaires and interviews to collect data. 261 teachers were involved as respondents to answer a questionnaire that was distributed, and 12 respondents were taken part in interviews. Quantitative data were analyzed using Statistical Package for the Social Sciences while qualitative data were analyzed using thematic analysis. The findings show that the principal role in enhancing the competence of teachers is still at a moderate level, and the pedagogic aspect of teachers at SMK Padang is still at a moderate level. This study also specified that education role of principal were significant influenced the teacher pedagogic. Further, the role of principal supervision was also significant in improving the pedagogical aspect of teachers.
\end{abstract}

Keywords: educator and supervisor roles, principal, teacher pedagogic

\begin{abstract}
Abstrak: Pendidikan Indonesia sedang membicarakan kompetensi guru, kaitannya dengan peran kepala sekolah dalam meningkatkan aspek pedagogis guru. Tujuan utama dari penelitian ini adalah untuk menentukan peran kepala sekolah sebagai pendidik dan pengawas dalam meningkatkan aspek pedagogik guru di Sekolah Kejuruan di Kota Padang, Sumatera Barat, Indonesia. Desain penelitian menggunakan metode campuran dilakukan berdasarkan pedoman dalam mencapai tujuan penelitian. Pengumpulan data menggunakan kuesioner dan wawancara pada 261 orang guru, sedangkan informan untuk menjawab pertanyaan dalam wawancara dilakukan pada 12 orang guru. Data kuantitatif dianalisis menggunakan Paket Statistik Ilmu Sosial sedangkan data kualitatif dianalisis menggunakan analisis tematik. Temuan penelitian menunjukkan bahwa peran kepala sekolah sebagai pendidik dan pengawas dalam meningkatkan kompetensi guru masih berada pada tingkat sedang, dan aspek pedagogik guru di SMK Padang masih berada pada tingkat sedang. Penelitian ini juga menetapkan bahwa peran kepala sekolah sebagai pendidik dan pengawas secara signifikan mempengaruhi kompetensi pedagogik guru.
\end{abstract}

Kata Kunci: peran pendidik dan pengawasan, kepala sekolah, kompetensi pedagogik

Tingkat pembangunan pendidikan untuk mencapai kualitas tinggi diharapkan dapat menghancurkan halhal pesimis yang diciptakan oleh semua negara di dunia termasuk Indonesia. Salah satu aspek penting dari upaya untuk meningkatkan kualitas pendidikan adalah meningkatkan kualitas guru dengan cara meningkatkan kompetensi guru secara maksimal sesuai dengan persyaratan kelayakan kompetensi profesional guru. Guru profesional harus memiliki empat kompetensi profesional guru, yaitu kompetensi pedagogi, kompetensi kepribadian, kompetensi sosial dan kompetensi profesional.

Kompetensi profesional guru adalah kemampuan dan keterampilan guru dalam melakukan tugasnya untuk kelancaran proses belajar mengajar yang berlangsung di kelas, dan menentukan proses tingkat 
kinerja serta kualitas pengajaran dan pembelajaran (Blankmeyer, dkk., 2002). Oleh sebab itu, kompetensi profesional pendidik perlu dilakukan dengan baik (Undang-undang Nomor 20 Tahun 2003 tentang Sistem Pendidikan Nasional; Peraturan Pemerintah Nomor 19 Tahun 2005 tentang Standar Nasional Pendidikan; Zulfikar, 2009), karena guru merupakan faktor penentu dalam mencapai keunggulan dalam pendidikan. Selain itu kompetensi guru, sangat dipengaruhi oleh peran kepemimpinan kualitas pendidikan kepala sekolah (Muhson, 2004; Yasril, 2013; Yuyarti, 2009; Ghafar \& Arbak, 2008).

Studi tentang peran kepala sekolah dilakukan oleh Arni (2007) pada sekolah di Kota Padang menemukan bahwa peran kepala sekolah memiliki hubungan yang signifikan dengan guru-guru berprestasi, sementara kompetensi guru dapat meningkatkan kualitas pendidikan. Selanjutnya, studi tentang peran kepala sekolah terhadap kompetensi guru dalam meningkatkan kualitas pendidikan oleh Ross (2008) ditemukan bahwa peran kepala sekolah memiliki hubungan yang signifikan terhadap kompetensi guru, sedangkan kompetensi guru memiliki hubungan positif terhadap kualitas mengajar dan belajar.

\section{METODE}

Penelitian ini dilakukan dengan menggunakan kombinasi metode kuantitatif dan kualitatif khususnya Concurrent Embedded Mixed Method Design (Creswell, 2014; Rittichainuwat \& Rattanaphinanchai, 2015; Bentahar \& Cameron, 2015). Metode kuantitatif dan kualitatif dilakukan secara bersamaan dalam penelitian untuk mendapatkan data yang komprehensif, valid, andal, dan objektif (Creswell, 2008). Penggunaan metode campuran belum seimbang karena tujuan penelitian dan pertanyaan penelitian, hanya satu tujuan dan pertanyaan penelitian yang menggunakan metode kualitatif untuk menjadi dominan adalah penelitian kuantitatif. Penelitian kualitatif dilakukan untuk mendukung penemuan jawaban yang lebih pasti dari masalah yang menyebabkan rendahnya kompetensi guru di kota Padang. Implementasi penelitian yang dilakukan dengan Mixed Method Design simultan tidak seimbang atau metode kuantitatif digunakan sebagai metode utama yang persentase lebih tinggi, sedangkan metode kualitatif digunakan sebagai metode pendukung persentase yang lebih rendah (Creswell, 2008).

Penelitian ini dilakukan di 10 sekolah menengah kejuruan (SMK) Negeri Padang, dengan jumlah sampel 261 orang guru. Teknik pengambilan sampel yang digunakan dalam penelitian ini adalah teknik random sampling (pengambilan sampel acak). Sedangkan populasi dengan metode kualitatif dalam penelitian ini adalah kepala sekolah dan guru di SMK Padang yang memenuhi kriteria tertentu menggunakan teknik purposive sampling. Data kuantitatif akan dianalisis dengan statistik deskriptif dan inferensial dengan bantuan SPSS 21. Data kualitatif dianalisis dengan menggunakan analisis tematik menjadi mudah dengan bantuan analisis lintas kasus.

\section{HASIL}

\section{Hasil Analisis Kuantitatif}

Peran kepala sekolah sebagai pendidik ditemukan sederhana, nilai rata-rata 3,65 dengan standar deviasi 0,783; yang berarti bahwa peran kepala sekolah sebagai seorang pendidik juga perlu ditingkatkan untuk meningkatkan kompetensi guru di Sekolah Menengah Kejuruan (SMK) Kota Padang. Jumlah frekuensi dan persentase juga menunjukkan peran utama sebagai pendidik berada pada kategori sederhana, kemudian sedang hingga tingkat tinggi untuk dimensi ini sedikit demi sedikit semakin tinggi. Dimana jumlah frekuensi untuk titik skala 4 lebih dari setengah dari 138 dan 52,9 persen. Ada juga ditemukan bahwa peran utama seorang manajer berada pada kategori sederhana karena hanya 3:45 dengan nilai rata-rata dari standar deviasi 0,749 . Sedangkan jumlah kemunculannya adalah mayoritas berada pada poin skala 4 dari 115 atau 44,1 persen. Lebih jauh, ini berarti bahwa kemampuan kepala sekolah untuk meningkatkan perannya dalam meningkatkan kompetensi guru masih perlu ditingkatkan.

Peran kepala sekolah sebagai pengawas secara bertahap moderat sebagai nilai rata-rata hanya 3:51 dengan standar deviasi 0,719. Berapa kali menunjukkan hal yang sama karena mayoritas responden 
memberikan persepsi tentang peran kepala sekolah pada skala 4 poin, 114 atau 43,7 persen, dan skala 3 poin, 100 atau 38,3 persen. Peran kepala sekolah sebagai pemimpin juga terjadi secara bertahap karena nilai rata-rata dengan standar deviasi 0,775 (3:37). Jumlah frekuensi dan persentase harus dibuat karena mayoritas pendukung berada pada skala 3 poin dengan frekuensi 114 atau 43,7 persen, dan skala 4 poin, 102 atau 39,1 persen. Ini berarti bahwa peran kepala sekolah sebagai seorang pemimpin belum dirasakan oleh para guru dalam meningkatkan kompetensi mereka. Hal ini ditunjukkan dengan tingkat kompetensi pedagogik guru masih berada pada kategori sederhana karena nilai rata-rata dengan standar deviasi 0,646 (3:50).

Ditemukan bahwa secara keseluruhan data berada pada skala 4 poin, 139 atau 53,3 persen. Ini berarti bahwa guru belum memiliki kompetensi tingkat tinggi dalam pedagogi. Ini menarik karena seharusnya guru memiliki keterampilan pedagogis dalam menjalankan tugasnya sebagai pendidik.. Namun, apa yang terjadi, ternyata tidak demikian. Bagian ini menjelaskan temuan penelitian untuk mengidentifikasi peran utama prediksi kompetensi guru dan alat analisis yang digunakan adalah analisis regresi linier berganda. Hasil analisis regresi linier berganda seperti pada Tabel 1 menunjukkan bahwa pengaruh keseluruhan kompetensi guru terhadap peran kepala sekolah adalah signifikan karena $\mathrm{F}$ signifikan (12.984) adalah 0.000. Hasil peran signifikan kompetensi guru adalah signifikan dan hipotesis kelima tidak dapat diterima atau ditolak sebagai sig 0,000 kurang dari nilai 0,05 . Pada Tabel 1, penelitian ini juga ditemukan bahwa efek peran dimensi utama adalah 28,7 persen. Ini berarti bahwa secara keseluruhan pengaruh peran kepala sekolah hanya 28,7 persen, atau ada faktor lain yang mempengaruhi kompetensi guru tetapi tidak dimasukkan dalam penelitian. Ini didukung oleh konstanta atau konstanta setinggi 3,338 dan nilai signifikan 0,000 (Tabel 1).

\section{Tabel 1 Hasil Analisis Regresi}

\begin{tabular}{|c|c|c|c|}
\hline VariabelIndependen & $\bar{\beta}$ & $t$ & Sig \\
\hline Konstanta & 3.338 & 20.871 & .000 \\
\hline Peran pendidikan & .148 & 2.406 & .017 \\
\hline Peran pengawasan & .244 & 4.056 & .000 \\
\hline $\begin{array}{l}\text { Variabel Dependen: Pedagogik Guru } \\
\text { adj } R^{2}=.287 \\
R=.514 \mathrm{~F}=12.984 \\
\mathrm{R}^{2}=.309 \mathrm{sig}=.000\end{array}$ & & & \\
\hline
\end{tabular}

Peran utama sebagai pendidik adalah signifikan karena nilainya secara signifikan lebih kecil dari nilai 0017 yaitu 0,05 . Temuan ini berarti bahwa sebagai pendidik seharusnya kepala sekolah dapat mempengaruhi kemampuan keberhasilan kompetensi guru di SMK Negeri Padang. Ada yang sama untuk peran kepala sekolah sebagai pengawas, sebagai inovator dan motivator memiliki nilai signifikan lebih kecil dari nilai alpha. Peran kepala sekolah sama pentingnya dengan pengawas 0,000 secara signifikan lebih kecil dari nilai 0,05 . Temuan ini berarti bahwa sebagai pendidik seharusnya kepala sekolah dapat mempengaruhi kemampuan keberhasilan kompetensi pedagogik guru di SMK Negeri Padang. Ada yang sama untuk peran kepala sekolah sebagai pengawas, sebagai inovator dan motivator memiliki nilai signifikan lebih kecil dari nilai alpha.

\section{Hasil Analisis Kualitatif}

Temuan penelitian kualitatif akan diuraikan menjadi dua bagian utama, yaitu penelitian sesuai dengan pertanyaan penelitian, khususnya bagaimana tingkat kompetensi guru di SMK Padang; masalah yang dihadapi kepala sekolah dalam meningkatkan kompetensi guru; masalah yang dihadapi oleh guru untuk meningkatkan kompetensi mereka; dan dorongan apa yang telah diberikan kepala sekolah untuk meningkatkan kompetensi guru. Penelitian lebih lanjut menggunakan analisis tematik dengan analisis lintas kasus untuk memastikan bahwa pendapat kepala sekolah dan guru di setiap tema adalah apakah dalam peran kepala sekolah dan kompetensi guru. Urutan yang akan diuraikan dalam penelitian kualitatif ini dimulai dari peran kepala sekolah sesuai dengan tema yang ada sebagai pendidik, manajer, 
administrator, pengawas, pemimpin, inovator dan motivator. Selanjutnya pada tema kompetensi guru kompetensi pedagogis, kepribadian, sosial dan profesional. Penelitian ini juga akan didahului oleh persentase responden yang diwawancarai. Peran sebagai pendidik dan pengawas tersedia secara bertahap lebih sederhana karena para guru juga secara bertahap moderat dalam aspek pedagogis mereka. Oleh karena itu peran kepala sekolah sangat disambut baik yang dapat meningkatkan tingkat pedagogi guru.

Secara keseluruhan, tampaknya tingkat kompetensi pedagogis moderat lebih dominan secara bertahap sesuai dengan temuan dari wawancara responden. Ada empat responden yang mengatakan bahwa pedagogi guru di SMK Padang sederhana dan dua di antaranya dikatakan bertahap. Temuan ini berarti bahwa guru benar-benar perlu meningkatkan aspek pedagogi yang memiliki standar pengetahuan yang sesuai yang ditetapkan oleh pemerintah. Apalagi aspek pedagogis ini terkait langsung dengan pengetahuan siswa sehingga perbaikan segera dan mendesak. Untuk menjelaskan secara rinci, pernyataan berikut akan diuraikan setiap responden. Tingkat kompetensi guru yang rendah tidak masuk akal agar siswanya dapat mencapai kualitas tinggi karena rasio kompetensi pedagogis secara langsung dikaitkan dengan pengetahuan siswa. Karena rendahnya kompetensi pedagogik guru, pemerintah perlu memberikan bantuan kepada guru untuk meningkatkan kompetensi pedagogis. Salah satu cara yang dapat dilakukan pemerintah adalah membantu para guru untuk dapat menambahkan kemampuan untuk memperluas pedagogi pendidikan guru ke tingkat yang lebih tinggi atau membantu memasukkan para guru di semua lokakarya yang sesuai dengan bidang keahlian para guru yang terlibat.

\section{PEMBAHASAN}

Aspek utama dalam upaya untuk memberikan kualitas tinggi kelulusan siswa adalah dengan meningkatkan kualitas pendidikan serta meningkatkan peran pedagogis guru (Aziz, 2012; Tondeur, dkk., 2017). Negara-negara maju telah melakukan berbagai perubahan sehubungan dengan kemampuannya untuk meningkatkan kualitas pendidikan (Walke, 1982; Hall \& Simpson, 2016; Procter, dkk., 2015; Miller, dkk., 2017). Potensi peningkatan dalam pendidikan tidak akan terlepas dari apa peran kepala sekolah dan kompetensi guru. Seperti di Amerika Serikat, Walke (1982) lebih lanjut menjelaskan bahwa sekolah menciptakan situasi yang mendukung proses pembelajaran yang berkualitas, peran kepala sekolah sebagai pemimpin sangat diperlukan.

Dukungan dari kepala sekolah saja tidak cukup karena guru adalah orang-orang yang secara langsung mengajar siswa sehingga penting juga bahwa kompetensi guru dengan standar (Jimenez, dkk., 2016; Knievel, dkk., 2015; Kaiser, dkk., 2015). Rendahnya aspek pedagogik guru dalam ujian berbasis kompetensi guru menyebabkan pemerintah sangat memperhatikan kualitas pendidikan Indonesia di masa depan. Oleh karena itu, Presiden Republik Indonesia mengusulkan kepada Kementerian Pendidikan Nasional untuk melakukan upaya dalam meningkatkan kompetensi guru yang diberi tugas dan peran guru sangat penting untuk mempersiapkan pemimpin masa depan (Peraturan Menteri Pendidikan Nasional Nomor 16 Tahun 2007 tentang Standar Kualifikasi Tenaga Pendidik).

Pernyataan tersebut didukung oleh Rosyada (2004) dan Rifma (2013) yang menyatakan bahwa guru harus memiliki kompetensi yang baik untuk dirinya sendiri sebagai pendidik profesional untuk meningkatkan kualitas pendidikan. Peran yang kurang sebagai pendidik dan pengawas akan berdampak pada penurunan kompetensi pedagogis guru (Murray \& Murray, 2004; Musfah, 2011; Muhson, 2004; Yasril, 2013; Yuyarti, 2009; Ghafar \& Arbak, 2008). Jadi peran level rendah itu juga menyebabkan tingkat kompetensi guru rendah.

\section{SIMPULAN}

Temuan dibahas dan dibandingkan dengan temuan penelitian sebelumnya untuk menentukan situasi nyata yang berlaku dalam peran kepala sekolah dalam meningkatkan kompetensi guru di SMK Padang. Studi ini menemukan bahwa tingkat kompetensi pedagogis guru meningkat karena studi sebelumnya kompetensi guru rendah, sedangkan penelitian menemukan kompetensi guru yang rendah. Selain itu, penelitian ini menetapkan bahwa peran kepala sekolah pendidikan, dan pengawasan berpengaruh 
signifikan terhadap pedagogi guru. Namun, tingkat peran kepala sekolah dalam meningkatkan kompetensi pedagogik guru berada di tingkat sedang. Oleh karena itu, peran kepala sekolah dalam aspek pendidikan dan pengawasan perlu memberikan kesempatan untuk mendapat manfaat lebih besar terutama untuk meningkatkan pedagogi guru.

\section{DAFTAR RUJUKAN}

Arni, M. (2007). Komunikasi Organisasi. Jakarta: PT Bumi Aksara.

Aziz, M. A. (2012). Effects of Demographic Factors and Teachers' Competencies on the Achievement of Secondary School Students in the Punjab. Gomal University Journal of Research, 28(1), 18-41.

Bentahar, O., \& Cameron, R. (2015). Design and Implementation of a Mixed Method Research Study in Project Management. Electronic Journal of Business Research Methods, 13(1), 1-15.

Blankmeyer, M. Flannery, D. J., \& Vazsonyi, A, T. (2002). The Role of Aggression and Sosial Competencein Childrend's Perceptions of the Child-Teachar Relationship. Psychology in the School, 39(3), 293-304.

Creswell, J. W. (2008). Educational Research: Planning, Conducting and Evaluating Quantitative and Qualitative Research. New York: Pearson Education International.

Creswell, J. W. (2014). Research Design: Qualitative, Quantitative, and Mixed Method Approaches. California: Sage Publications, Inc.

Ghafar, M. N. A., \& Arbak, T. (2008). Gaya Kepimpinan Pengetua dan Ciri-ciri yang Efektif. Jurnal Pendidikan Universiti Teknologi Malaysia, 13, 73-84.

Hall, A. H., \& Simpson, A. (2016). Working to Improve the Quality of Care for Young Children in One Community Organization. Journal of Community Engagement \& Higher Education, 8(4), 1-17.

Jiménez, A. M., Fernández, B. G. B., \& Franco, M. T. (2016). How Spanish Science Teachers Perceive the Introduction of Competence-Based Science Teaching. Journal of Baltic Science Education, 15(3), 371-381.

Kaiser, G., Busse, A., Hoth, J., König, J., \& Blömeke, S. (2015). About the Complexities of Video-Based Assessments: Theoretical and Methodological Approaches to Overcoming Shortcomings of Research on Teachers' Competence. International Journal of Science and Mathematics Education, 13(2), 369-387.

Knievel, I., Lindmeier, A. M., \& Heinze, A. (2015). Beyond Knowledge: Measuring Primary Teachers' SubjectSpecific Competences in and for Teaching Mathematics with Items Based on Video Vignettes. International Journal of Science and Mathematics Education, 13(2), 309-329.

Miller, A., Eather, N., Gray, S., Sproule, J., Williams, C., Gore, J., \& Lubans, D. (2017). Can Continuing Professional Development Utilizing A Game-Centred Approach Improve the Quality of Physical Education Teaching Delivered by Generalist Primary School Teachers? European Physical Education Review, 23(2), 171-195.

Muhson, A. (2004). Meningkatkan Profesionalisme Guru: Sebuah Harapan. Jurnal Ekonomi dan Pendidikan, 2(1), $1-18$.

Murray, C., \& Murray, K. M. (2004). Child Level Correlates of Teacher-Student Relationships: An Examination of Demographic Characteristics, Academic Orientations, And Behavioral Orientations. Psychology in the Schools, 41(7), 15-22.

Musfah, J. (2011). Peningkatan Kompetensi Guru Melalui Pelatihan dan Sumber Belajar Teori dan Praktik. Jakarta: Kencana.

Peraturan Menteri Pendidikan Nasional Nomor 16 Tahun 2007 tentang Standar Kualifikasi Tenaga Pendidik. Jakarta: Fokus Media.

Peraturan Pemerintah Nomor 19 Tahun 2005 tentang Standar Nasional Pendidikan. Jakarta: Fokus Media.

Procter, S., Irwin, J., Mazhindu, D., Nayoan, J., \& Smith, F. (2015). Increasing Understanding of the Best Ways to Collect and Use Feedback from Students and Trainees in Order to Improve the Quality of Education and Training.

Rifma, N. (2013). Model Pembinaan Kompetensi Pedagogik Guru Sekolah Dasar. Disertasi tidak diterbitkan. Padang: Program Pascasarjana Universitas Negeri Padang.

Rittichainuwat, B., \& Rattanaphinanchai, S. (2015). Applying a Mixed Method of Quantitative and Qualitative Design in Explaining the Travel Motivation of Film Tourists in Visiting a Film-Shooting Destination. Tourism Management, 46, 136-147.

Ross, D. (2008). Leadership Style of Secondry School Principles as Perceived by Secondary School Teachers. Disertasi tidak diterbitkan. Florida: Florida Atlantic Universiy. 
Rosyada, K. (2004). Paradigma Pendidikan Demokratis: Sebuah Model Pelibatan Masyarakat dalam Penyelenggaraan Pendidikan. Jakarta: Kencana.

Tondeur, J., van-Braak, J., Ertmer, P. A., \& Ottenbreit-Leftwich, A. (2017). Understanding the Relationship between Teachers, Pedagogical Beliefs and Technology use in Education: a Systematic Review of Qualitative Evidence. Educational Technology Research and Development, 65(3), 555-575.

Undang-undang Nomor 20 Tahun 2003 tentang Sistem Pendidikan Nasional. Jakarta: Fokus Media.

Walke, R. S. (1982). Effects of Principal Inservice Training on Teacher Classroom Behaviors and Student Academic Motivation. Florida: Florida Atlantic Universiy.

Yasril, F. (2013). Kontribusi Kepemimpinan Pengetua Sekolah dan Profesionalitas Guru terhadap Kinerja Guru pada SMP Negeri di Kecamatan Sutera. Tesis tidak diterbitkan. Padang. Program Pascasarjana Universitas Negeri Padang.

Yuyarti. (2009). Peranan Pengetua Sekolah dalam Manajemen Peningkatan Mutu Pembelajaran. Jurnal Litbang Prov. Jawa Tengah, 7(2), 133-140.

Zulfikar, T. (2009). The Making of Indonesia Education: An Overview on Empowering Indonesia Teachers. Indonesia Social Sciences and Humanities, 2(2), 1-7. 